\title{
THE IMPLEMENTATION OF CONSIGNMENT SALES ON GOLDEN VOICE ONLINE STORE SEMARANG
}

\author{
Saifudin ${ }^{1}$ \\ Nurul Rahmawati ${ }^{2}$ \\ Citra Rizkiana ${ }^{3}$
}

Faculty of Economics, Semarang University (USM), Indonesia

\begin{abstract}
This study was conducted at Golden Voice Online Store Semarang. The purpose of this study is to analyze the implementation of consignment sales and the recording method used in Golden Voice Online Store. This study uses qualitative method of case study by using triangulation of data sources, namely observation, interview and documentation. The sources of the data taken were the data from Golden Voice Online Store. The results of this study indicate that in the financial statements, Golden Voice Online Store has not recorded the consignment in accordance with the applicable Accounting Standard. The method of accounting recording for consignment sales used is inseparabled method.
\end{abstract}

Keywords: Consignment, Accounting, Recording Method.

\section{INTRODUCTION}

The development of the business world is increasing from time to time, with the level of competition is getting higher and harder. Every company always has annual target, and can penetrate the target with various strategies that have been prepared and worked on. There are several sales strategies undertaken by the current companies, such as sales in cash, sales by order, sales in installment, sales in consignment and others. But the problems often hit the company to achieve the target is about marketing the product caused by various aspects, including the competition from similar companies, market saturation and others that add to the company's difficulties. One way to overcome the problem is by performing the consignment sales.

\footnotetext{
${ }^{1}$ saifudin@usm.ac.id; Faculty of Economics, Semarang University

2rahma.199108@gmail.com; Faculty of Economics, Semarang University

${ }^{3}$ citra@usm.ac.id; Faculty of Economics, Semarang University
} 
Consignment sales are sales by agreement, whereby the owners of the goods / consignor / safety guard, submit the goods to another party, namely the consignee / commissioner to be sold to outsiders and the consignee gets commission from the consignor (Halim, 2015). In this case it is very possible because by making consignment sale many parties will become partners in working together. The recipient of the deposit (the commissioner) is not burdened with a certain amount of liability until the goods received are sold. Thus the areas that become the company's marketing targets will be more easily affordable, because they already have collaborative partner to market the company's products and consumers in the area can get the products at the same price.

Golden Voice Online Store is a trading business that sells turtledove fodder and accessories. This online store performs sales by consignment and takes sides as safety guard. For it, through the sale by consignment, it can expand the marketing area of fodder products without having to expense too much costs, with the hope that the products can be known by wider community and arouse the interests of consumers without having to go far away to buy directly to Golden Voice Online Store to get prices according to the market. The business owner hopes to get the opportunity to develop the business through the availability of the consignment goods.

The results of the pre survey conducted by the researchers found that consignment goods have been marketed to various regions in Indonesia. The product price is the same from one commissioner to another. It is expected that the selling price in the market will be the same among the sellers who have become commissioners, so that the consumers from the regions who buy the product do not need to go far to buy directly to Golden Voice Online Store because the prices offered by the commissioners in their area are pegged at the same price. For the requirements as commissioners are not the same one to another, due to different regional constraints so that in providing free shipping fee or other bonuses are adjusted. This agreement has been discussed previously in order to avoid problem or unfair thing for one of the parties in the future. The things that are in the provisions as commissioners will affect the sales results that will be received by Golden Voice Online store, thus it will affect the profit that will be received.

Although Golden Voice produces its own turtledove fodder and performs sales consignment, in this case it also sells independently either via online or purchases products at the production site directly by consumers. Then the profits earned are from consignment sales and regular sales. Golden Voice Online Store is still a MSME 
business with all the records are conducted manually and easily understood for the admin and also the owner in checking the reports. In addition, the records the reporting system are integrated for the commissioners, so that there is no difference between the sales report for consignment and regular sales.

The consignment is recognized by Golden Voice Online Store as stock of trading goods that should still become the property of the safety guard when the commissioners have not yet made full payment. In addition, in making the consignment sales report to the safety guard, it does not include shipping costs. For the management, reporting and recording of consignment goods, it must apply appropriate accounting treatment to comply with generally accepted accounting standards and principles, so that the system of recording the sales reports can be properly and safely maintained.

\section{THEORITICAL BACKGROUND}

Financial accounting standards (2014) in PSAK No. 23 concerning income stated that sales of goods include goods produced by the company to be sold and goods bought to be re-sold such as goods purchased by retailers or land or other properties purchased for resale. Sales of services usually involve carrying out tasks that are contractually agreed upon to be carried out for a period agreed by the company, these services can be delivered for one period or more than one period. Sales of goods that are not from the core business will not be included in the sales account. The types of sales are as follows:

1. Cash sales

2. Credit Sales

3. Consignment Sales

\section{The Definition of Consignment}

"Halim (2015) stated that consignment sales are sales by agreement, whereby the owner of the goods / consignor / safety guard submits the goods to another party, namely the consignee / commissioner to be sold to outside parties and the consignee gets a number of commissions from the consignor".

\section{Terms in Consignment Accounting}

The following are the terms in consignment sales accounting according to several experts, including according to Halim (2015) "Goods sent by consignor are called consignment goods (consignment out) and goods received by consignee are called commission goods (consignment in)". 
According to Afriyanto (2014), the parties involved in the consignment are:

1. Safety guard (consignor) is the party who entrusts the goods or the owner of the goods. The safety guards will remain recording the items they entrusted as inventory as long as the items entrusted have not been sold or waiting for the report from the commissioner.

2. The commissioner (consignee) is the party who receives the goods of consignment sales, in the everyday sense it is known as sales by depositing.

\section{The Characteristics of Consignment Transaction}

According to Halim (2015), the things that must be considered in consignment sales are as follows:

1. At the time of the financial statement preparation, commission items in the consignee may not be counted / recognized as its inventories.

2. Consignment goods shipment may not be counted / recognized as sales by the consignor before the goods are sold to outside parties.

3. At the time of the financial statement preparation, consignment goods in the consignee must be calculated / recognized by the consignor as its inventories.

4. All expenses related to consignment / commission goods from the time of shipment until sold are the responsibility of the consignor.

5. Consignee within certain limits are obliged to maintain and retain the safety of the commission goods received.

\section{The Advantages of Consignment Sales for the Safety Guard (Consignor)}

According to Yunus and Harnanto (2013), there are several reasons why the safety guard (consignor) chooses consignment sales, namely:

1. Consignment is a way to further expand the market that can be guaranteed by a producer, manufacturer or distributor, especially if:

a. The goods concerned have just been introduced, the demand for products is not certain and not yet well-known.

b. Past sales through dealers are not profitable.

c. The price of goods becomes expensive and requires substantial investment for the dealers if they have to buy the goods. 
2. Certain risks can be avoided by safety guard. Consignment goods are not confiscated if there is bankruptcy at the consignee. So, it is different from the agency or dealer agreement.

3. The retail price of the goods concerned can still be controlled by the safety guard, as well as the number of goods that are ready to be marketed and the stock of the goods.

\section{The Advantages of Consignment Sales for Commissioner (Consignee)}

According to Yunus and Harnanto (2013) there are several reasons why the commissioner (consignee) chooses consignment sales, namely:

1. The consignee is protected from the possibility of failure risk to market the goods for having to sell at loss.

2. The damage risk of the goods and price fluctuations can be avoided.

3. The need for working capital can be reduced, because there are consignment goods that are received or deposited by the safety guard.

\section{The Terms and Agreements of Consignment Sales}

Hidayat (2012) argues that in the delivery of goods on consignment basis, a written contract (agreement) must be drawn up showing the nature of the relationship between the party who give and receive the goods. The written contract includes:

1. Credit conditions that must be given by the commissioner to the customer.

2. Expenses issued by the commissioner must be replaced by the safety guard.

3. Commission or profits that must be given to the commissioner.

4. Remittance and financial settlement by the commissioner.

5. Report that must be sent by the commissioner.

\section{The Recording of Consignment Sales}

According to Afriyanto (2014), there are two methods used for consignment sales accounting both by consignee and commissioner:

1. The net method, that is, consignment transactions recorded separately from regular sales transactions.

2. Gross method, that is, consignment transactions recorded inseparablely from ordinary sales transactions.

The following is journal illustration that can be seen in the table, either the recording by consignee or commissioner with the separate profit method or the inseparable profit method. 


\section{Table 1}

Journal illustration of consignee with separate profit method

\begin{tabular}{|c|c|}
\hline Transaction & Journal Verse \\
\hline $\begin{array}{l}\text { 1. Consignment } \\
\text { delivery }\end{array}$ & $\begin{array}{l}\text { Consignment goods - Goods Delivery } \\
\text { Inventory }\end{array}$ \\
\hline $\begin{array}{l}\text { 2. Payment for transportation } \\
\text { cost of consignment goods }\end{array}$ & $\begin{array}{l}\text { Consignment Goods - Tansportation Cost XXX } \\
\text { Cash } \\
\mathrm{XXX}\end{array}$ \\
\hline $\begin{array}{l}\text { 3. Receiving liability reports } \\
\text { containing sales, costs and } \\
\text { income to be received from } \\
\text { commissioner }\end{array}$ & $\begin{array}{lc}\text { Commissioner Receivable } & \text { XXX } \\
\text { Consignment Goods - Commission Cost } & \text { XXX } \\
\text { Consignment Goods - Sales } & \text { XXX }\end{array}$ \\
\hline $\begin{array}{l}\text { 4. Receiving payments from } \\
\text { commissioner }\end{array}$ & $\begin{array}{l}\text { Cash } \\
\qquad \text { Receivable - Commissioner }\end{array}$ \\
\hline
\end{tabular}

Table 2

Journal illustration of consignee with inseparable profit method

\begin{tabular}{|c|c|c|c|}
\hline Transaction & \multicolumn{3}{|c|}{ Journal Verse } \\
\hline $\begin{array}{l}\text { 1. Payment for transportation } \\
\text { cost of consignment goods }\end{array}$ & $\begin{array}{l}\text { Transportation Cost } \\
\text { Cash }\end{array}$ & XXX & $\mathrm{XXX}$ \\
\hline $\begin{array}{l}\text { 2. Receiving liability report } \\
\text { containing sales, costs and } \\
\text { income to be received from } \\
\text { commissioner }\end{array}$ & $\begin{array}{l}\text { Commissioner Receivable } \\
\text { Commission Cost } \\
\text { Sales } \\
\text { Cost of Goods Sold } \\
\text { Inventory }\end{array}$ & $\begin{array}{l}\mathrm{XXX} \\
\mathrm{XXX} \\
\mathrm{XXX}\end{array}$ & XXX \\
\hline $\begin{array}{l}\text { 3. Receiving payment from } \\
\text { commissioner }\end{array}$ & $\begin{array}{l}\text { Cash } \\
\qquad \text { Receivable - Comm }\end{array}$ & XXX & $\mathrm{XXX}$ \\
\hline
\end{tabular}


Table 3

Journal illustration of commissioner with separate profit method

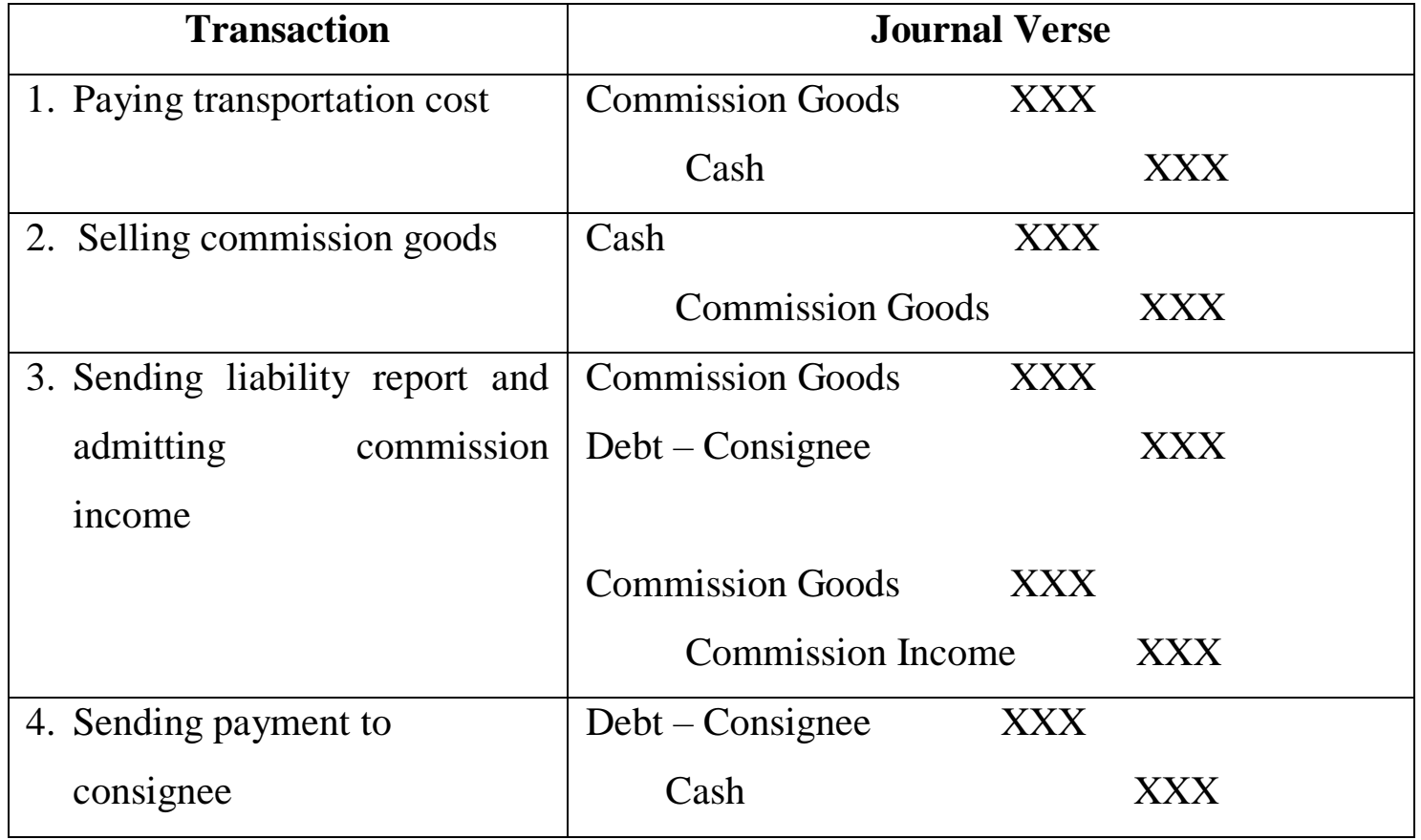

Table 4

Journal illustration of commissioner with inseparable profit method

\begin{tabular}{|c|c|c|c|}
\hline Transaction & Journ: & Verse & \\
\hline 1. Paying transportation cost & $\begin{array}{l}\text { Debt - Consignee } \\
\text { Cash }\end{array}$ & $\mathrm{XXX}$ & $\mathrm{XXX}$ \\
\hline 2. Selling commission goods & $\begin{array}{l}\text { Cash } \\
\qquad \text { Sales } \\
\text { Purchasing } \\
\text { Debt - Consignee }\end{array}$ & XXX & XXX \\
\hline $\begin{array}{l}\text { 3. Sending payment to } \\
\text { consignee }\end{array}$ & $\begin{array}{c}\text { Debt }- \text { Consignee } \\
\text { Cash }\end{array}$ & XXX & $\mathrm{XXX}$ \\
\hline
\end{tabular}

\section{FLOWCHART OF CONSIGNMENT SALES}

According to Mulyadi (2010), Data Flow Chart is a model that describes the flow of data and the process to process data in a system. Processing symbol is used to indicate the places in the information system that processes or converts data received into money flowing out. 


\section{Figure 1}

Flowchart of Consignment Sales Procedure at the Time of Delivering Goods
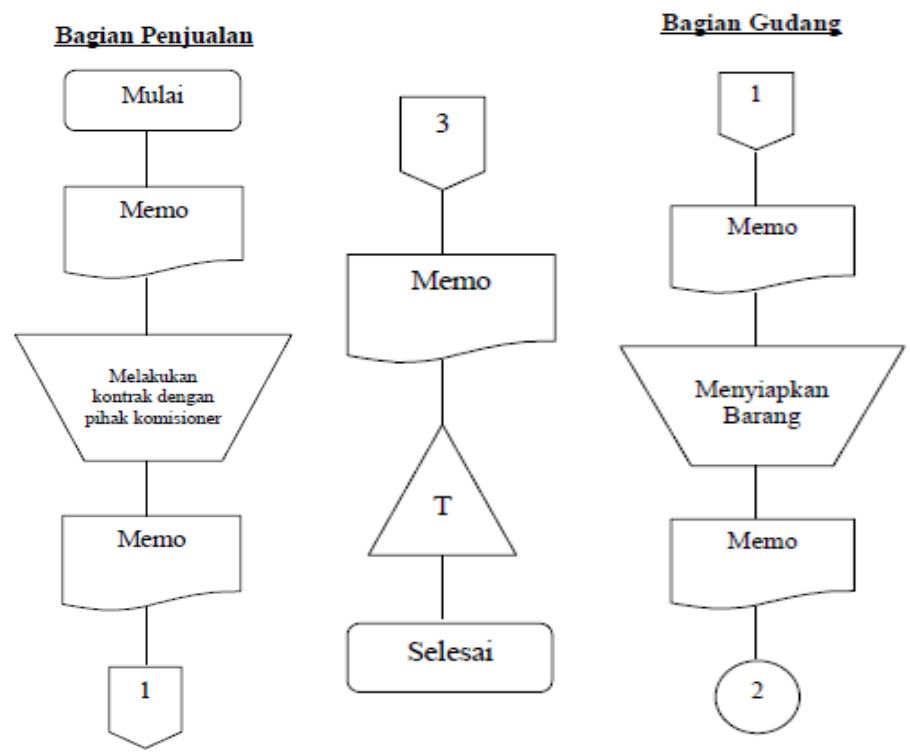

Bagian Pengiriman

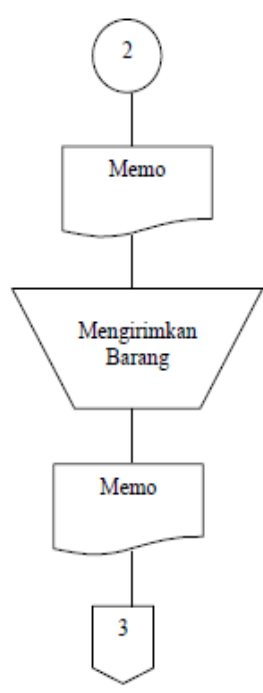

Note: Memo (Memorial Evidence)

Figure 2

Flowchart of Consignment Sales Procedure at the Time of Goods Sold

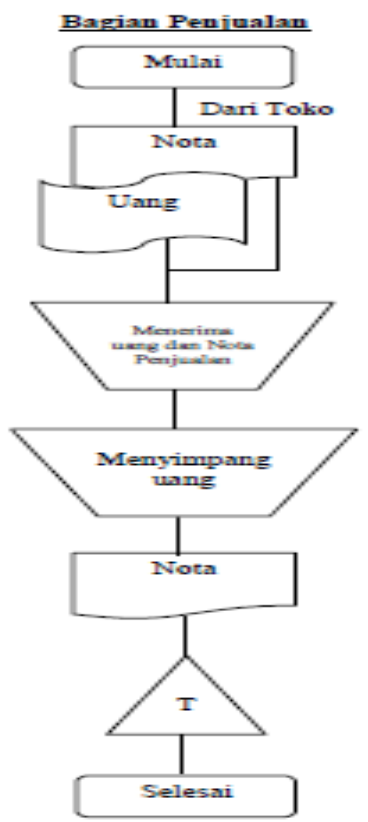

Note: Note (Note of Sales Evidence) 


\section{RESEARCH IDEA FLOW}

The following is is a picture of the research idea flow used by the researchers:

Figure 3

\section{Research Idea Flow}

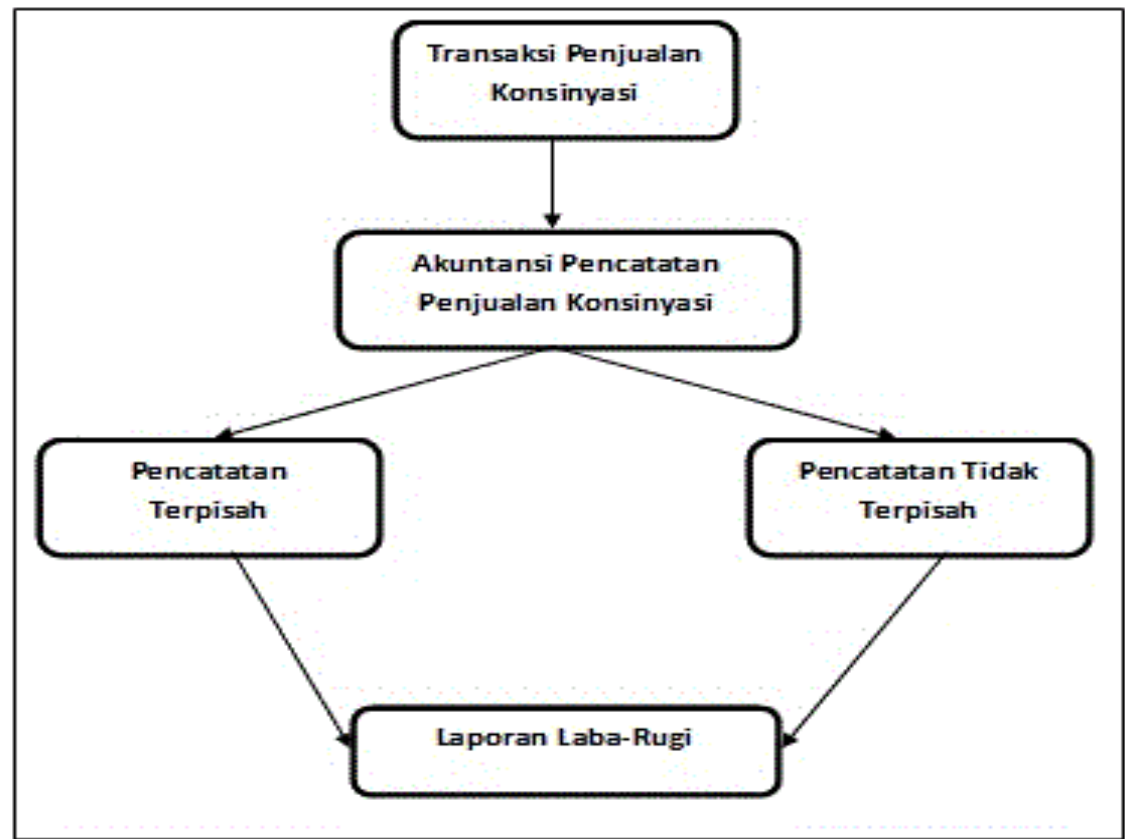

This framework of thinking explains how Golden Voice Online Store conducted consignment sales transaction. After that, the researchers explained how the consignment sales accounting records were made. So that analysis of recording made by Golden Voice Online Store will be made.

\section{METHOD, DATA AND ANALYSIS}

\section{Type of research}

This type of research uses qualitative method with the interviewees consisted of the owner, the person responsible for consignment sales, and several commissioners. The data collection technique uses triangulation technique. The type of approach that the researchers conducted is case study. Case study is empirical evidence from one or more organizations, and researchers try to study the problems in their context.

\section{Research data type}

Research data can come from various sources, collected using various techniques throughout the research process. Data sources used are primary data and secondary data. Primary data is source of data obtained from the first party without going through intermediary. Primary data is specifically collected by researcher to answer research 
questions. Primary data can be in the form of the opinion of the subject (people) both in group and individually, the results of observations of an object (physical), events or activities, and research results. While secondary data are internal data that are already available and have been collected by other parties.

\section{Place and time of research}

This research was carried out at Golden Voice turtledove fodder production house located at Jalan Borobudur Utara VI no. 25 Semarang. Research time is the time used to obtain accurate data, so the study was conducted from April 2019 to July 2019.

\section{Research subject and object}

The case study research subject is the informant as the source of the research data, the informant is considered understand, comprehend and master the information / data according to the research topic. The research subjects here are the owner, leader of Golden Voice Online Store and also the production house, namely Mr. Nanang Eko, Mrs. Sri Rahayu as part of the administration and commissioner who have family relationship.

The research objects examined were consignment sales and regular sales as well as potential sales results at Golden Voice Online Store.

\section{Method of collecting data}

\section{Observation Technique}

Observation technique was done by conducting direct observation to the company, in this case carried out at Golden Voice online store Semarang.

2. Oral Interview and Written interview

Oral and written interviews were conducted with the informants, namely question and answer and direct discussions with the company, especially the administration which directly records the consignment goods and other employees as well as several commissioners who frequently conduct transactions.

\section{Documentation}

Documentation can be in the form of administration records, correspondence, memo, agendas, photo and other relevant documents by requesting or retrieving documents in the form of sales data from Golden Voice Online Store. 


\section{RESULT AND DISCUSSION}

\section{The Implementation of Consignment Sales Accounting at Golden Voice Online Store}

Halim (2015) stated that consignment sales are sales by agreement, whereby the owner of the goods / consignor / safety guard submits the goods to another party, namely the consignee / commissioner to be sold to outside parties and the consignee gets a number of commissions from the consignor.

In the implementation of consignment sales accounting, Golden Voice Online Store has been good at understanding the basics of consignment sales both of the terms used in communication and also in recording the report. But there are still terms that are used generally, in order to facilitate work.

According to Halim (2015), consignment sales need to be considered. But so far not all have been noticed by Golden Voice Online Store because there are several points in the agreement that are adjusted to the conditions of Golden Voice Online Store and the characteristics that must be considered. Characteristics that have been considered by Golden Voice Online Store are:

1. The status of consignment goods which are the property of the consignee is still often misinterpreted as the commissioner's inventory when it is in the commissioner's warehouse.

2. The transportation cost will be the responsibility of the commissioners, when the demand for goods does not match the amount agreed.

The benefits of consignment sales for Golden Voice Online Store are as follows:

1. No need to have its own sales or marketing to sell and introduce products widely. With this commissioner, the products to be sold are expected to be spread throughout the region, because many have become commissioners and are located in regional areas.

2. Golden Voice Online Store can control the quantity and price of goods in the market, so that the selling price will be the same between one commissioner to another even though sometimes there are commissioners who still sell prices above the price specified.

Based on observation conducted at Golden Voice Online Store, some of the agreements that have been made and agreed are still not executed properly. Like the recognition of consignment products as inventory for commissioners, the consignee who does not 
directly inform the change in product price to the commissioner. It will affect the profits received both for the consignee and commissioner.

The following is consignment sales system used by golden voice online store:

\section{Figure 4}

\section{Flowchart of Consignment Sales Procedure at the Time of Delivering Goods}

\section{According to Golden Voice Online Store}
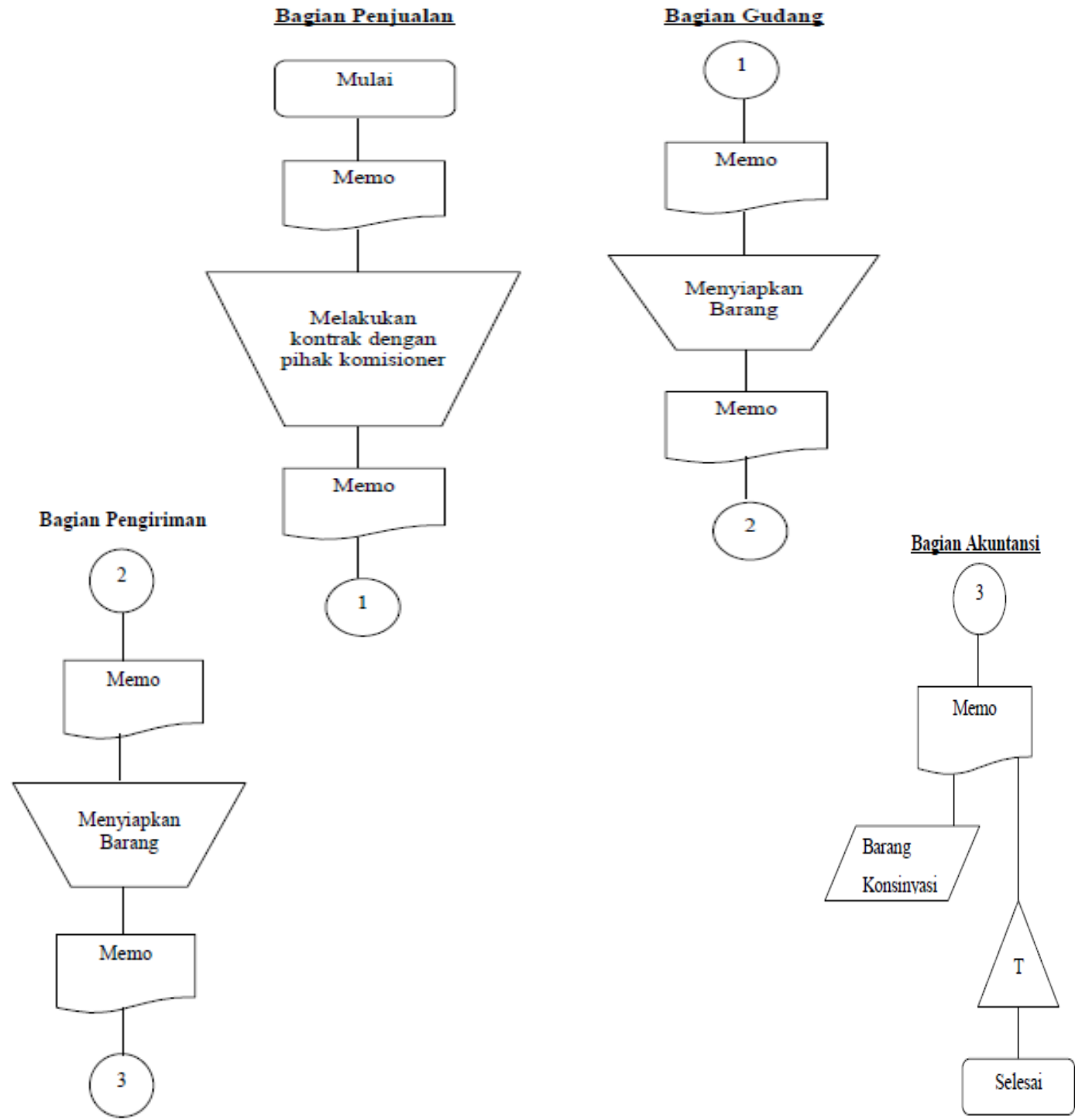

Note : Memo (Memorial Evidence)

Source : Golden Voice Online Store Semarang,2019 
The explanation of Figure 4, flowchart of consignment sales procedure at the time of delivering goods:

\section{Sales Department}

The accounting system of consignment goods sales at the time of delivering goods at golden voice online store, begins with the sales department conducting contract or agreement for safekeeping of goods. Then after the contract is agreed, the sales department makes a memo for the consignment goods delivery order, then the memo is sent to the warehouse department.

2. Warehouse Department

The warehouse receives memo from the sales department, then prepares the consignment goods directly according to the amount stated on the memo. Then the warehouse department sends the goods that have been prepared with the memo to the shipping department.

\section{Shipping Department}

The shipping department receives consignment goods along with memo from warehouse department, then matches the goods with the description of the number of goods that must be sent based on the memo. After that the shipping department sends the goods to the commissioners and sends memo to the accounting department.

\section{Accounting Department}

The accounting department (in this case the administration department) receives memo from the shipping department, then based on the memo the accounting department makes the journal of the consignment goods sent at the same time archiving the memo. 
Figure 5

The Flowchart of Consignment Sales at the Time of Goods Sold According to Golden Voice Online Store
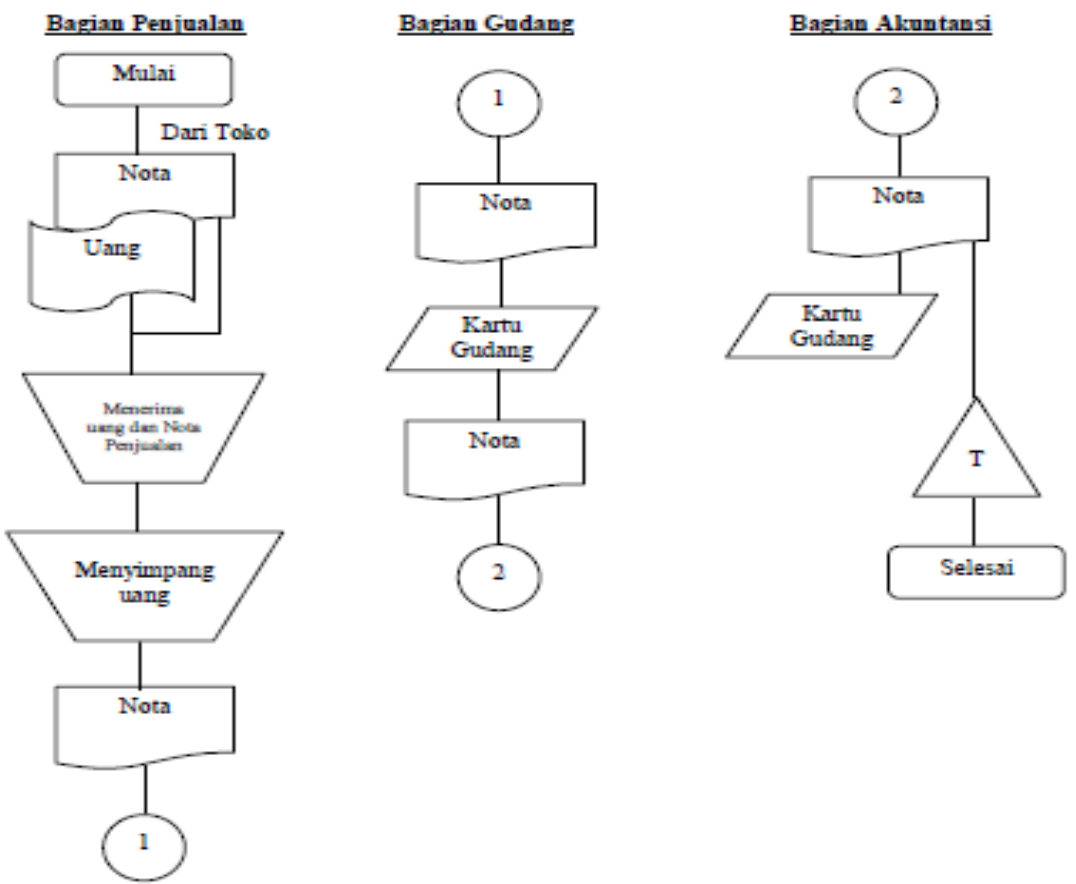

Note : Note (Cash Sales Evidence)

Source : Golden Voice Online Store Semarang,2019

The explanation of Figure 5, flowchart of consignment sales procedure at the time of delivering goods:

1. Sales Department

The Sales Department receives a sum of money along with sales note from the commissioner, then saves the money in cash and sends the note to the warehouse department.

2. Warehouse Department

The warehouse department receives note from the sales department, then based on the note writes on the warehouse card regarding the number of goods that have been sold. Then the warehouse department sends the note to the accounting department.

\section{Accounting Department}

The accounting department receives note from the warehouse department. Then based on the note, the accounting department records it into the cash acceptance journal and archives the note. 


\section{The Sales Recording Method Used by Golden Voice Online Store}

The method of recording the sales used by Golden Voice Online Store is inseparable method. This method is used for reasons of easy use, though not in detail in the records. At the end of the period it is not even necessary to make closing journal. This method records all sales of both consignment sales and regular sales into one report, but in this case at the end of the period Golden Voice Online Store will not know the profit from consignment sales and how much profit from the regular sales.

The profit recording of consignment sales at Golden Voice Online Store will be recorded from each commissioner and each sales of goods is more clear according to the report sent by the commissioners, so that it will be concluded which commissioners who sells more consignment goods.

\section{CONCLUSION}

Based on the results of data analysis and discussion, conclusions can be made as follows:

1. The recording of consignment goods when sent by the consignee and received by the commissioners is not in accordance with the concept of consignment sales accounting science where recording is only based on invoices and does not record (journalize) as it should be.

2. The reporting of consignment sales results from commissioners to the consignee is not accompanied by recording (journalizing) as it should be.

3. The recording method used by the consignee is inseparable method that is considered easier because it does not separate the consignment sales from regular sales. But it is rather difficult to see which sales are greater at the end of the period because they are not detailed. The commissioners prefer the recording of separate method, to make it easier in reporting consignment sales to the consignee.

4. Consignment agreements made by the consignee are agreed upon properly by the commissioner, from the deposit agreement, the minimum order and payment to be made. But there are commissioners who sell products above the specified selling price, which means that they violate the agreed agreement.

5. In presenting the consignment sales profit / loss statement conducted by Golden Voice Online Store is the inseparable method. In this method the operating profit generated by Golden Voice Online Store is the same as the operating profit generated by the separate method. The difference in the presentation of profit / loss statements 
between separate method and inseparable method is on the presentation of profit / loss statements. By using the inseparable method, it is not known in detail between operating income from consignment sales and operating income from regular sales.

\section{SUGGESTION}

Based on the conclusion, the suggestions that can be given are:

1. The consignee should increase the understanding on consignment sales to avoid misperception, so that they can know the exact profit calculation.

2. It is recommended that the consignee uses 3-fold note in order to control the consignment sales made.

3. To make the sales report can be easily read for the profit and loss, good records are needed in accordance with accounting standards as in the presentation of profit / loss statements.

The limitation of this research is that although it is able to contribute to scientific findings, the managerial implications of this study are designed by adjusting the situation and conditions as well as the needs, therefore the results of the study may not be directly generalized to other companies in general.

The results of this study can be used as reference and hand book to assist further research. In the subsequent studies, it is recommended that the researchers do not only pay attention to the method used in influencing earnings, but can include several variables about increasing profits and applying consignment accounting in accordance with the standards.

The researchers are also expected to be able to read more references or other sources of literature so that further research can be more developed and varied. 


\section{REFERENCES}

Afriyanto. 2014. Financial Accounting I. Module. Rokan Hulu.

Arifin, 2010. Main Financial Accounting Principles, Revised Edition. Liberty: Yogyakarta.

Emzir, 2016. Qualitative Research Methodology, Data Analysis. PT Raja Grafindo Persada: Jakarta

Halim, Abdul, 2015. Advance Financial Accounting. Mitra Wacana Media: Jakarta Handayani, Sutri, 2018. "The Analysis of Potential Sales Outcomes on the Smoothness Payment of Consignment Goods at Clothing Stores of PD Storey Market Lamongan", Research Journal of Economics and Accounting, Volume III No.3, ISSN

Kuncoro, Mudrajad, 2013. Research Methods for Business \& Economics, $4^{\text {th }}$ Edition. Erlangga: PT.Gelora Aksara Pratama

Lailin Ni'mah, Novaria \& Baihaki, Ach, 2018. "Accounting for Consignment Sales in Increasing Profit at Hollida Pamekasan Home Industry". National Seminar on Economics, Management \& Accounting, ISSN-UIM

Mulyadi, 2010. Accounting System. Salemba Empat: Jakarta

Samryn, LM, 2015. Introduction to Accounting. PT Raja Grafindo Persada: Jakarta

Sugiono, 2008. Quantitative, Qualitative and R\&D Research Methods. Alfabeta: Bandung

Suradi, 2009. Introduction to Accounting 1. Gava Media: Yogyakarta

Wijaya, Rika et al., 2018, "The Implementation of Consignment Sales Accounting on the Employees Cooperation Prima of Hospital Wijaya Kusuma", Progress Conference - STIE WIDYA GAMA, Lumajang, Volume I, No.1.

Yendrawati, Reni. 2008. Advance Financial Accounting I. EKONISIA: Yogyakarta. 
ATTACHMENT OF INTERVIEW RESULTS

\begin{tabular}{|c|c|c|c|c|}
\hline Question & Owner & $\begin{array}{l}\text { Administration } \\
\text { Department }\end{array}$ & $\begin{array}{c}\text { Commissioner } \\
1\end{array}$ & Commissioner 2 \\
\hline $\begin{array}{l}\text { 1. What type of } \\
\text { recording } \\
\text { method is } \\
\text { used, } \\
\text { separate } \\
\text { method or } \\
\text { inseparable } \\
\text { method? }\end{array}$ & $\begin{array}{l}\text { a. Inseparable } b \\
\text { method is } \\
\text { used } \\
\text { because it } \\
\text { is easier }\end{array}$ & $\begin{array}{l}\text { b. Using } \\
\text { inseparable } \\
\text { method and } \\
\text { additional } \\
\text { notes for } \\
\text { regular sales }\end{array}$ & $\begin{array}{l}\text { a. Inseparable } \\
\text { method is } \\
\text { wider } \\
\text { because } \\
\text { recording is } \\
\text { conducted in } \\
\text { detail }\end{array}$ & $\begin{array}{l}\text { a. Simple sales } \\
\text { recording and } \\
\text { inseparable so, } \\
\text { both consignment } \\
\text { sales and regular } \\
\text { sales are recorded } \\
\text { into one report. } \\
\text { When we should } \\
\text { report to the } \\
\text { supervisor, we } \\
\text { should select it } \\
\text { first. }\end{array}$ \\
\hline Question & Owner & $\begin{array}{c}\text { Administration } \\
\text { Department }\end{array}$ & $\begin{array}{c}\text { Commissioner } \\
1\end{array}$ & Commissioner 2 \\
\hline 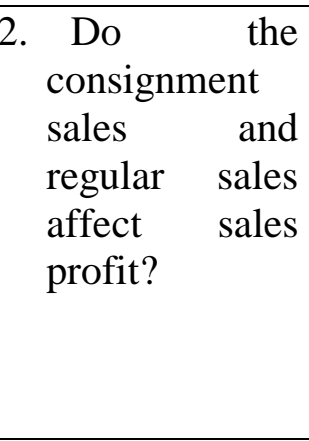 & $\begin{array}{l}\text { a. Different } \\
\text { sales price, } \\
\text { different } \\
\text { profit gained. } \\
\text { b. Regular sales } \\
\text { profit is } \\
\text { greater than } \\
\text { consignment } \\
\text { sales }\end{array}$ & $\begin{array}{l}\text { a. Both } \\
\text { consignment } \\
\text { and regular } \\
\text { sales influence } \\
\text { sales profit. } \\
\text { b. Recording is } \\
\text { conducted } \\
\text { separately to } \\
\text { make it clearer }\end{array}$ & $\begin{array}{l}\text { a. The result is } \\
\text { same, but the } \\
\text { recording is } \\
\text { different. }\end{array}$ & $\begin{array}{l}\text { a. The recording is } \\
\text { different, the sales } \\
\text { result is the same. }\end{array}$ \\
\hline $\begin{array}{l}\text { 3. What is the } \\
\text { nature of HPP } \\
\text { for } \\
\text { consignee and } \\
\text { commissioner? }\end{array}$ & $\begin{array}{l}\text { HPP is the } \\
\text { production } \\
\text { costs to make } \\
\text { a selling } \\
\text { product }\end{array}$ & $\begin{array}{l}\text { Benchmark } \\
\text { price is prior to } \\
\text { the sale price } \\
\text { to } \\
\text { commissioner } \\
\text { or to the } \\
\text { market }\end{array}$ & $\begin{array}{l}\text { HPP is the } \\
\text { price given by } \\
\text { the consignee } \\
\text { with costs }\end{array}$ & $\begin{array}{l}\text { HPP is the price } \\
\text { given by the } \\
\text { consignee with } \\
\text { costs }\end{array}$ \\
\hline $\begin{array}{l}\text { 4. How is the } \\
\text { treatment of } \\
\text { consignment } \\
\text { goods? }\end{array}$ & $\begin{array}{l}\text { Consignment } \\
\text { goods are } \\
\text { entrusted to } \\
\text { commissioner } \\
\text { and are still } \\
\text { property of the } \\
\text { consignee. }\end{array}$ & $\begin{array}{l}\text { Inventory is } \\
\text { reduced when } \\
\text { the product is } \\
\text { sent to the } \\
\text { commissioner } \\
\text { but has not } \\
\text { been referred } \\
\text { to as revenue } \\
\text { or receivable }\end{array}$ & $\begin{array}{l}\text { Recognized as } \\
\text { a stock that is } \\
\text { ready to be } \\
\text { sold to } \\
\text { consumers }\end{array}$ & $\begin{array}{l}\text { Recognized as a } \\
\text { stock that is ready } \\
\text { to be sold to } \\
\text { consumers }\end{array}$ \\
\hline
\end{tabular}




\begin{tabular}{|c|c|c|c|c|}
\hline Question & Owner & $\begin{array}{c}\text { Administration } \\
\text { Department }\end{array}$ & $\begin{array}{c}\text { Commissioner } \\
1\end{array}$ & Commissioner 2 \\
\hline $\begin{array}{l}\text { 5. Is the } \\
\text { consignment } \\
\text { agreement } \\
\text { carried out } \\
\text { properly? }\end{array}$ & $\begin{array}{l}\text { Agreement } \\
\text { is agreed to } \\
\text { and done } \\
\text { without } \\
\text { harming } \\
\text { any parties. }\end{array}$ & $\begin{array}{l}\text { Well and not } \\
\text { detrimental to } \\
\text { related parties }\end{array}$ & $\begin{array}{l}\text { Have received } \\
\text { the rights and } \\
\text { carried out the } \\
\text { obligations in } \\
\text { accordance } \\
\text { with applicable } \\
\text { regulations. }\end{array}$ & $\begin{array}{l}\text { In accordance with } \\
\text { agreements that have } \\
\text { been mutually } \\
\text { agreed upon, and } \\
\text { without harming } \\
\text { related parties. }\end{array}$ \\
\hline $\begin{array}{l}\text { 6. Is the sales } \\
\text { reporting time } \\
\text { appropriate? }\end{array}$ & $\begin{array}{l}\text { a. The profit } \\
\text { / loss } \\
\text { financial } \\
\text { statement } \\
\text { s are } \\
\text { reported } \\
\text { monthly. } \\
\text { b. Sales } \\
\text { reports are } \\
\text { reported } \\
\text { once a } \\
\text { week. }\end{array}$ & $\begin{array}{l}\text { a. The } \\
\text { profit / loss } \\
\text { financial } \\
\text { statements are } \\
\text { reported to the } \\
\text { owner at the } \\
\text { end of each } \\
\text { period, which } \\
\text { is once a } \\
\text { month. Sales } \\
\text { b. are } \\
\text { reports once } \\
\text { reported once } \\
\text { a week, which } \\
\text { is in the } \\
\text { beginning of } \\
\text { the week. }\end{array}$ & $\begin{array}{l}\text { Consignment } \\
\text { sales report is } \\
\text { done every } \\
\text { time there are } \\
\text { goods sold. }\end{array}$ & $\begin{array}{l}\text { Consignment sales } \\
\text { repor is done once a } \\
\text { week. }\end{array}$ \\
\hline
\end{tabular}




\begin{tabular}{|c|c|c|c|c|}
\hline Question & Owner & \begin{tabular}{|c|} 
Administration \\
Department
\end{tabular} & $\begin{array}{c}\text { Commissioner } \\
1\end{array}$ & Commissioner 2 \\
\hline $\begin{array}{l}\text { 7. Is the sales } \\
\text { reporting } \\
\text { time } \\
\text { appropriate? }\end{array}$ & $\begin{array}{l}\text { a. The } \\
\text { profit / loss } \\
\text { financial } \\
\text { statements } \\
\text { are reported } \\
\text { monthly. } \\
\text { b. Sales } \\
\text { reports are } \\
\text { reported } \\
\text { once a week. }\end{array}$ & $\begin{array}{l}\text { a. The } \\
\text { profit / loss } \\
\text { financial } \\
\text { statements are } \\
\text { reported to the } \\
\text { owner at the } \\
\text { end of each } \\
\text { period, which } \\
\text { is once a } \\
\text { month. Sales } \\
\text { b. are } \\
\text { reports ance } \\
\text { reported once } \\
\text { a week, i.e in } \\
\text { the beginning } \\
\text { of the week. }\end{array}$ & $\begin{array}{l}\text { Consignment } \\
\text { sales report is } \\
\text { done every } \\
\text { time there are } \\
\text { goods sold. }\end{array}$ & $\begin{array}{l}\text { Consignment sales } \\
\text { report is done once a } \\
\text { week. }\end{array}$ \\
\hline $\begin{array}{l}\text { 8. How is the } \\
\text { recording of } \\
\text { financial } \\
\text { statements? }\end{array}$ & $\begin{array}{l}\text { The } \\
\text { recording of } \\
\text { financial } \\
\text { statements } \\
\text { used } \\
\text { inseparable } \\
\text { method. }\end{array}$ & $\begin{array}{l}\text { The recording } \\
\text { of financial } \\
\text { statements } \\
\text { used } \\
\text { inseparable } \\
\text { method. }\end{array}$ & $\begin{array}{l}\text { The recording } \\
\text { of financial } \\
\text { statements } \\
\text { used separate } \\
\text { method } \\
\text { Pencatatan } \\
\text { laporan } \\
\text { keuangan } \\
\text { menggunakan } \\
\text { metode } \\
\text { terpisah }\end{array}$ & $\begin{array}{l}\text { The recording of } \\
\text { financial statements } \\
\text { used } \\
\text { method }\end{array}$ \\
\hline
\end{tabular}

Source: Results from Informants Interview Analysis,2019 